\title{
The moderating role of entrepreneurship education in shaping entrepreneurial intentions
}

\author{
Iqtidar A. Shah ${ }^{1 *}$, Sohail Amjed ${ }^{2}$ and Said Jaboob ${ }^{3}$
}

*Correspondence:

ishah@yorkvilleu.ca

${ }^{1}$ Department of Business

Administration, Yorkville

University, New Westminster,

BC, Canada

Full list of author information

is available at the end of the

article

\begin{abstract}
Few studies investigated the role of entrepreneurship education in students' entrepreneurial intentions. These studies produced controversial results which invited the attention of researchers for further investigations. This paper examines the moderating role of entrepreneurship education on the predictive value of attitude, subjective norms and self-efficacy for entrepreneurial intentions. True Experimental Design (post-test-only control group design) is used to investigate the change in the nature and magnitude of the impact of independent variables (personal attitude, self-efficacy and subjective norms) on the dependent variable (intentions) using entrepreneurship education as a moderating variable. Data were collected from the treatment group (completed entrepreneurship course) and control group (not taken entrepreneurship course) from various higher education institutions in Oman. Total 500 questionnaires were distributed, out of which 204 filled questionnaires were received back in which 196 qualified as valid responses. Structural equation modeling was used to test hypotheses. The statistical relationship among the modeled variables was estimated using Partial Least Square method. The results revealed that attitude toward entrepreneurship, subjective norms and self-efficacy are the significant predictors of entrepreneurial intentions. However, entrepreneurship education moderates this relationship by strengthening the path coefficients of attitude toward entrepreneurship and selfefficacy. Same time it weakens the path coefficient of subjective norms.
\end{abstract}

Keywords: Attitude, Entrepreneurship, Intention, Knowledge, Pre-experimental design, Skills

\section{Introduction}

Unemployment is a universal concern of all developed and developing countries. The rate of unemployment has been mounting all over the world, especially with the recent global meltdown (Taha et al. 2017). Various policies and strategies have been adopted worldwide to reduce unemployment. Among the most chosen alternative solution to unemployment problem is entrepreneurship (Nazri et al. 2016) as entrepreneurship is increasingly considered as a significant generator of economic growth, innovation and creation of jobs (Badulescu and Badulescu 2013). However, entrepreneurship development and changing the mindset of people toward entrepreneurship is itself a challenge for almost all countries. The policymakers have adopted numerous strategies and techniques to promote entrepreneurship. One of the strategies is 
to provide entrepreneurship education to the people to increase the level of entrepreneurship (European Commission 2006). Entrepreneurship education provides students with the motivation, knowledge and skills that are essential for launching a successful venture (Lee et al. 2005). The purpose of entrepreneurship education is to train students to acquire skills, ideas and managerial abilities, and capacities of selfemployment rather being employed for pay (Owoseni and Akambi 2010). Another objective is to help students to consider business as a career by developing positive attitudes toward entrepreneurship (Fayolle and Gailly 2008).

The Sultanate of Oman is one of the most important oil-producing countries in the Middle East. The economy of the Sultanate of Oman is based on oil production and export. For the last many years, Oman is striving to diversify its economy to reduce oil dependency and reduce the ever-increasing unemployment. The Sultanate of Oman is facing a big challenge of unemployment among the youth, especially university graduates. Increased access to higher education in Oman has increased unemployment because absorbing graduates into the public sector in an expensive and unsuitable course of action and private sector is mostly occupied by expatriate workforce (Magd and McCoy 2014). The unemployment rate in Oman increased from $17.30 \%$ (2015) to $17.50 \%$ (2016). The average unemployment rate is recorded 18.34\% from 1991 until 2016 (Trading Economics 2018). The labor market in Oman is currently saturated and unable to absorb the increasing number of the labor force. Therefore, the Oman government has made considerable efforts to boost and support entrepreneurship to create sufficient job opportunities by encouraging small-medium enterprises. Many supportive and motivate initiatives (financial, guiding, training and mentoring) have been taken including Intilaaqah, National Business Centre (NBC), Riyada-Public Authority for SME Development, Sas Programme, Sharakah (Fund for Development of Youth Projects), Zubair Small Enterprise Centre (Zubair SEC), CELL Program, Oman American Business Council, Injaz, Aiesec Oman and Jisser Internship Platform (Startup Oman 2018).

Entrepreneurship education has also received amplified attention in Oman. Various pilot projects and national, regional or international programs have been implemented to promote entrepreneurship and to provide entrepreneurship education especially among youth, students and unemployed. The vocational training centers and colleges of technology are supporting entrepreneurship education to enhance entrepreneurial skills of graduating students. The two chains of colleges namely College of technology (under the Ministry of Manpower) and College of Applied Sciences (under the Ministry of Higher Education) are working to foster the entrepreneurship culture in the Sultanate. New courses have been offered to all students to all specializations and specific training programs on entrepreneurship skills are included in curricula (UNESCO, undated). However, the impact of changes in students' intentions toward entrepreneurship has never been assessed which is important for policymakers. Thus, there is a need for a study to assess students' intention toward entrepreneurship and the factors affecting their decisions. For this purpose, the study has adapted Theory of Planned Behaviour (TPB) model and added demographic factors (independent variable) as an additional variable and entrepreneurship education as a moderating variable by proposing the conceptual framework to investigate the impact of intervening factor (entrepreneurship 
education) on the relationship of dependent variable (intentions) and independent variables (personal attitude, personal norms, self-efficacy and demographic).

The main objective of this paper is to explore how entrepreneurial education is affecting the entrepreneurship intentions contributing to the future growth of entrepreneurship in Oman. More specific objectives are to find out how and to what extent the entrepreneurship education changes the students' attitude, capability, skills, knowledge and intentions toward entrepreneurship, to record students' willingness and capabilities to start their own business, to identify hindrance due to which students hesitate to start their own business and to find out the ways to stimulate and encourage student to start their own business.

The rest of the paper has been organized as follows: the brief account of existing literature related to the topic is presented in Sect. 2 followed by an explanation of the conceptual framework in Sect. 3. Section 4 describes the methodology adopted in the paper while results and discussion is carried out in Sect. 5. Paper is concluded in Sect. 6 with some policy implications.

\section{Literature review}

Extensive research related to students' entrepreneurial intentions exists (Taha et al. 2017; Sahinidis et al. 2014; Khuong and Huu An 2016; Rasli et al. 2013; Turker and Selcuk 2008). Understanding, studying and investigating intentions are very beneficial which provide valuable insights and help in determining the level of entrepreneurial activities. The assessment of students' entrepreneurial orientation, intention and interest toward entrepreneurship is important for the educational institutions and policymakers because entrepreneurial intention is the best predictor of entrepreneurial behavior or action of creating a new business (Krueger et al. 2000). Different variables employed in different studies have produced inconsistent empirical results (Thompson 2009). The two popular entrepreneurial intentions models, i.e., Entrepreneurial event theory (EET) (Shapero and Sokol 1982) and the Theory of Planned Behavior (Ajzen 1991) are widely used in literature for analyzing intentions toward entrepreneurship. According to EET model, entrepreneurship intentions are influenced by perceptions of personal desirability (attractiveness), feasibility (capabilities), and propensity to act upon opportunities (willingness). While in TPB model, the behavioral intentions are determined by three key antecedents: personal attitude (PA), personal norms (PN) or social norms and Perceived Behavioral Control (PBC) or perceived self-efficacy. Numerous other factors which influence the intention to be an entrepreneur are also widely investigated. Wang and Wong (2004) and Liñán et al. (2011) included the sociodemographic and other environmental and economic variables (age, gender, marital status, parent's occupation, household income, culture, opportunities' recognition, fear of failure, social background, previous employment, education, entrepreneurial skills and ability, financial support, ethnicity and religion) to examine the influence on intentions.

The impact of entrepreneurship education on intentions has been focused in many studies and found mixed results. The positive relation between entrepreneurial education and entrepreneurial intentions has been found by many authors (Costa et al. 2016). Packham et al (2010) and Mushtaq et al. (2011) investigated that education is significantly correlated with the intention to create a new venture. Similarly, Jaafar 
and Abdul Aziz (2008) also pointed out that entrepreneurship courses have a positive impact on people to start their own businesses at some point in their career. Entrepreneurship education increases the interest of people in becoming an entrepreneur (Cheng et al. 2009). Another study also confirmed that entrepreneurship education encourages students to take on entrepreneurship as a career and gives students the skills needed to be entrepreneurial (Fatoki and Oni 2014).

The review of studies that deal with the impact of entrepreneurship education yielded 41 papers, out of which 33 studies reporting a positive impact, six with mixed results, and only two reporting a negative impact of entrepreneurship education (Lorz et al. 2011). He identified that most studies that showed a positive impact of entrepreneurship education had significant methodological deficiencies, which strongly limited the validity of the results. He further indicated that most of the studies are ex-post examinations that do not measure the direct impact of an entrepreneurship education program or do not utilize control groups or have small samples. According to him, there are only four impact studies which have used an ex-ante, ex-post design with control groups and a sample size of $n>100$. Out of these, one study reporting positive results, two reporting mixed or insignificant results, and one reporting significantly negative results. This calls us for more studies using a robust research design. Previous studies found that there is a strong relationship between the students' intentions toward entrepreneurship and personal attitude, self-efficacy, subjective norms, demographic factors, and entrepreneurship education. However, less amount of research work is available in examining the impact of entrepreneurship education on the relationship of intentions and considered variables, especially in case of Omani students.

\section{Conceptual model and hypotheses}

The role of entrepreneurship education in assessing students' intentions toward entrepreneurship is explained in the conceptual framework (Fig. 1).

To find out the students' intentions toward entrepreneurship (dependent variable), three independent variables, i.e., personal attitude, self-efficacy and subjective norms, have been chosen as independent variables while entrepreneurship education is a moderating variable. These five independent variables have been chosen because of the potential impacts of entrepreneurship education on them which accordingly can change the students' intentions toward entrepreneurship. True Experimental Design (post-test-only control group design) is used to investigate the mediating role of entrepreneurship education in the relationship between independent variables and dependent variable. Data are collected from groups of students, i.e., a group of students who have completed entrepreneurship education and another group has not yet completed entrepreneurship courses. The results of both groups are compared to check the mediating role of entrepreneurship education.

The following hypotheses are developed:

H1 Personal attitude about entrepreneurship has a significant impact on students' intentions toward entrepreneurship. 


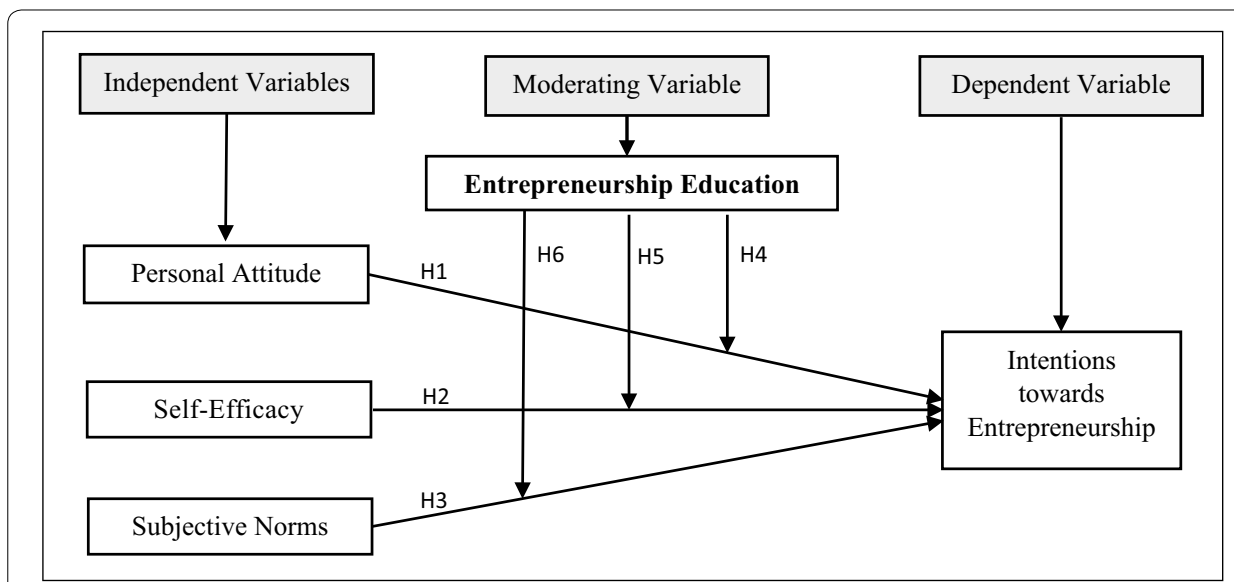

Fig. 1 Conceptual framework for evaluation of entrepreneurship education

H2 Self-efficacy has a significant impact on students' intentions toward entrepreneurship.

H3 Subjective norms have a significant impact on students' intentions toward entrepreneurship.

H4 Entrepreneurial education has a significant positive impact on the relationship of personal attitude and intention toward entrepreneurship.

H5 Entrepreneurial education has a significant positive impact on the relationship of self-efficacy and intention toward entrepreneurship.

H6 Entrepreneurial education has a significant positive impact on the relationship between subjective norms and intention toward entrepreneurship.

\section{Methodology}

\subsection{The study}

We assumed positivist research philosophy and quantitative approach to obtain evidence to affirm the theoretical assertions. We collected quantitative data through a self-administered survey. The target population is students at various higher education institutions of Sultanate of Oman, offering entrepreneurship course which is a mandatory course for all disciplines at undergraduate level. The study includes only Higher Education institutions working in Oman; therefore, we assume that courses and their contents would be at par with each other. The Sultanate of Oman has an active regulatory body, namely Oman Academic Accreditation Authority, to ensure that all higher education institutions weather public or private, and comply the standards set by this authority. Therefore, we can expect that the entrepreneurship courses offered at undergraduate level in higher education institutions across the country are homogenous with respect to contents and delivery. In this survey, a questionnaire comprising 33 questions 
was floated among the sampled units of the population. The unit of study of this research is an individual student in the higher education institutes of the Sultanate of Oman. The sultanate encourages higher education institutions to offer entrepreneurship courses to the students in various disciplines especially the business schools. We approached the higher education institutions, which are offering entrepreneurship courses, through personal contacts. The respondents were randomly selected using convenient sampling method. The randomly collected data were divided into two subgroups based on the course completion.

Informed consent was obtained from all the participants prior to the survey, and the confidentiality and anonymity of the responses were ensured. For data collection, we used the Entrepreneurial Intentions Questionnaire (EIQ) designed by Liñán and Chen (2009) with additional demographic questions (age, gender, course, father occupation, etc.). A question was also added in the questionnaire to ask if the participant has studied the entrepreneurship courses or otherwise. The sample was divided into two subgroups based on the entrepreneurship education: the treatment group who had completed entrepreneurship courses and control group who had not completed entrepreneurship courses. The two groups were chosen to compare the results in terms of student attitude toward entrepreneurship, subjective norms and self-efficacy which might change because of entrepreneurship education. More than 500 questionnaires were distributed in person to the students at various higher education institutions offering entrepreneurship courses in the Sultanate of Oman. Convenience sampling approach was used to obtain the responses from the subjects. Total of 204 completed questionnaires was collected back in person out of which 192 questionnaires were usable. Overall, the response rate was $41.4 \%$. Around $36 \%$ of the respondents were female and $64 \%$ were male. The average age of the respondents was 23 years. With regard to the entrepreneurship course, $55 \%$ of students in our sample have completed while $45 \%$ have not yet studied the course.

\subsection{Questionnaire and measures of the constructs}

The Entrepreneurial Intentions Questionnaire (EIQ), designed by Liñán and Chen (2009) is used to collect the data from the two groups of students, i.e., who have completed the course of entrepreneurship and students who have not yet completed entrepreneurship course. The EIQ was developed to measure entrepreneurship intentions (EI) and other variables such as attitude toward entrepreneurship (ATE), subjective norm (SN), and perceived behavioral control/self-efficacy (SE). Another variable, i.e., students' demographic factors (DF) is included in the same questionnaire. Reliability and validity of the questionnaire were already verified by Liñán and Chen (2009) to ensure that each pool of questions is related to the same subject and each subject corresponds to the required measure. However, we also performed the reliability and validity tests with collected data.

The questionnaire used in the research is divided into five sections. Section A identifies the profile/personal information of the respondents developed from various resources and own thought as well. Sections B, C, D and E comprehend questions related to attitude, subjective norms, self-efficacy and entrepreneurship intentions, respectively, taken 
Table 1 Details of construct

\begin{tabular}{|c|c|c|}
\hline Construct & Questions & Source \\
\hline \multirow[t]{7}{*}{ Demographic factors (DF) } & A1. Which is your field of study? & \multirow{5}{*}{$\begin{array}{l}\text { Luiz and Mariotti (2011), Reynolds } \\
\text { et al. (1994), Storey (1994), Delmar } \\
\text { and Davidsson (2000), Grilo and } \\
\text { Thurik (2005) }\end{array}$} \\
\hline & A2. In which age group you fall? & \\
\hline & A3. What is your gender? & \\
\hline & A4. Do you have work experience? & \\
\hline & A5. Where is your father working? & \\
\hline & $\begin{array}{l}\text { A6. Have you completed entrepre- } \\
\text { neurship courses? }\end{array}$ & Own thought \\
\hline & A7. What is your CGPA? & Own thought \\
\hline \multirow[t]{6}{*}{$\begin{array}{l}\text { Attitude toward entrepreneurship } \\
\text { (ATE) }\end{array}$} & $\begin{array}{l}\text { B1. Being an entrepreneur implies } \\
\text { more advantages than disadvan- } \\
\text { tages to me }\end{array}$ & \multirow[t]{5}{*}{ Liñán and Chen (2009) } \\
\hline & $\begin{array}{l}\text { B2. A career as entrepreneur is } \\
\text { attractive for me }\end{array}$ & \\
\hline & $\begin{array}{l}\text { B3. If I had the opportunity and } \\
\text { resources, I would like to start } \\
\text { a firm }\end{array}$ & \\
\hline & $\begin{array}{l}\text { B4. Being an entrepreneur would } \\
\text { entail great satisfaction for me }\end{array}$ & \\
\hline & $\begin{array}{l}\text { B5. Among various options, I would } \\
\text { rather be an entrepreneur }\end{array}$ & \\
\hline & $\begin{array}{l}\text { B6. It is attractive for me to become } \\
\text { an entrepreneur }\end{array}$ & $\begin{array}{l}\text { Solesvik et al. (2012), Liñán and Chen } \\
\text { (2006) }\end{array}$ \\
\hline \multirow[t]{6}{*}{ Subjective norms (SNR) } & $\begin{array}{l}\text { C1. My closest family members } \\
\text { think that I should pursue a } \\
\text { career as an entrepreneur }\end{array}$ & \multirow{3}{*}{$\begin{array}{l}\text { Liñán and Chen (2009), Heuer and } \\
\text { Kolvereid (2014), Liñán et al. (2011), } \\
\text { Solesvik et al. (2012), Souitaris et al. } \\
\text { (2007), Liñán and Chen (2006) }\end{array}$} \\
\hline & $\begin{array}{l}\text { C2. My closest friends think that } \\
\text { I should pursue a career as an } \\
\text { entrepreneur }\end{array}$ & \\
\hline & $\begin{array}{l}\text { C3. People that are important to } \\
\text { me think that I should pursue a } \\
\text { career as an entrepreneur }\end{array}$ & \\
\hline & $\begin{array}{l}\text { C4. Most people in my country } \\
\text { consider it acceptable to start } \\
\text { own business }\end{array}$ & \multirow[t]{3}{*}{$\begin{array}{l}\text { Heuer and Kolvereid (2014), Liñán } \\
\text { et al. (2011) }\end{array}$} \\
\hline & $\begin{array}{l}\text { C5. The culture in my country is } \\
\text { highly favorable toward entrepre- } \\
\text { neurial activity }\end{array}$ & \\
\hline & $\begin{array}{l}\text { C6. The entrepreneur's role in the } \\
\text { economy is generally valued in } \\
\text { my country }\end{array}$ & \\
\hline \multirow[t]{6}{*}{ Self-efficacy (SEF) } & $\begin{array}{l}\text { D1. To start a business and keep it } \\
\text { working would be easy for me }\end{array}$ & \multirow{6}{*}{$\begin{array}{l}\text { Liñán and Chen (2009), Solesvik et al. } \\
\text { (2012), Souitaris et al. (2007), Liñán } \\
\text { and Chen (2006) }\end{array}$} \\
\hline & $\begin{array}{l}\text { D2. I am prepared to start a viable } \\
\text { business }\end{array}$ & \\
\hline & $\begin{array}{l}\text { D3. As an entrepreneur, I would } \\
\text { have sufficient control over my } \\
\text { business }\end{array}$ & \\
\hline & $\begin{array}{l}\text { D4. I know the necessary practical } \\
\text { details to start a firm }\end{array}$ & \\
\hline & $\begin{array}{l}\text { D5. I know how to develop an } \\
\text { entrepreneurial project }\end{array}$ & \\
\hline & $\begin{array}{l}\text { D6. If I tried to start a firm, I would } \\
\text { have a high probability of suc- } \\
\text { ceeding }\end{array}$ & \\
\hline
\end{tabular}


Table 1 (continued)

\begin{tabular}{|c|c|c|}
\hline Construct & Questions & Source \\
\hline \multirow[t]{7}{*}{$\begin{array}{l}\text { Intentions toward entrepreneur- } \\
\text { ship (ITE) }\end{array}$} & $\begin{array}{l}\text { E1. I am ready to do anything to } \\
\text { start my own business }\end{array}$ & \multirow{4}{*}{$\begin{array}{l}\text { Liñán and Chen (2009), Dinis et al. } \\
\text { (2013), Solesvik et al. (2012), Liñán } \\
\text { and Chen (2006), Davidsson (1995) }\end{array}$} \\
\hline & $\begin{array}{l}\text { E2. My professional goal is to start } \\
\text { my own business }\end{array}$ & \\
\hline & $\begin{array}{l}\text { E3. I will make every effort to start } \\
\text { and run my own firm }\end{array}$ & \\
\hline & $\begin{array}{l}\text { E4. I am determined to create a firm } \\
\text { in the future }\end{array}$ & \\
\hline & $\begin{array}{l}\text { E5. I have very seriously thought of } \\
\text { starting a firm }\end{array}$ & $\begin{array}{l}\text { Liñán and Chen (2009), Solesvik et al. } \\
\text { (2012), Liñán and Chen (2006), } \\
\text { Davidsson (1995) }\end{array}$ \\
\hline & $\begin{array}{l}\text { E6. I intend to start a business } \\
\text { within } 5 \text { years of graduation }\end{array}$ & \multirow[t]{2}{*}{$\begin{array}{l}\text { Solesvik et al. (2012), Liñán and Chen } \\
\text { (2006), Davidsson (1995) }\end{array}$} \\
\hline & $\begin{array}{l}\text { E7. I have thought of entrepreneur- } \\
\text { ship as a career option }\end{array}$ & \\
\hline
\end{tabular}

the different constructs of the entrepreneurial intention model. These items are summarized in Table 1.

\section{Analysis, finding and discussions}

We used structural equation modeling to test the suggested hypotheses. The parameter coefficients among the modeled variables were estimated by Partial Least Square (PLS) method. We preferred PLS over covariance-based approaches due to the flexibility to handle more complex models in which moderating and mediating relations are tested (Lowry and Gaskin 2014; Hair et al. 2011). Moreover, it relaxes some binding assumptions such as normal distribution which is rarely met by social sciences data (Sarstedt et al. 2014). PLS is also preferred over covariance-based model due to better handling of small sample size (Chin 1998; Haenlein and Kaplan 2004; Hair et al. 2016; Sarstedt et al. 2017). According to Bartlett et al. (2001), there should be 10 responses for each indicator. By this standard, we must have 220 observations as we have 22 indicators in all four latent variables. However, we have 192 valid responses which are relatively small sample size; therefore, we preferred PLS method over covariance-based approach. To carry out analysis, we used Warp PLS 6.0 software which is capable of handling complex multiblock analysis consisting of formative and reflective latent variables (Hair et al. 2016).

\subsection{Measurement model}

At the first place, we checked the measurement quality of our constructs through various reliability and validity tests. At the first place, reliability of the construct was checked by performing the most commonly used tests of instrument reliability, namely Cronbach's Alpha and composite reliability. We used alternate test of reliability to ensure that our constructs are free from measurement bias. For testing the validity of instrument, we used combined loading and cross-loading method. We used average variance extracted (AVE) for convergent validity and square roots of AVE for discriminant validity. We checked the possibility of collinearity by variance inflation factor (VIF). 
Table 2 Composite reliability coefficients

\begin{tabular}{lllll}
\hline & ATE & SNR & SEF & ITE \\
\hline CRC & 0.914 & 0.912 & 0.931 & 0.940 \\
CBa & 0.887 & 0.884 & 0.911 & 0.925 \\
AVE & 0.640 & 0.634 & 0.693 & 0.691 \\
VIF & 1.983 & 2.068 & 1.747 & 2.044 \\
Correlations among I vs. with sq. rts. of AVEs & & & \\
ATE & 0.800 & 0.658 & 0.501 & 0.581 \\
SNR & 0.658 & 0.796 & 0.527 & 0.596 \\
SEF & 0.501 & 0.527 & 0.832 & 0.616 \\
ITE & 0.581 & 0.596 & 0.616 & 0.831 \\
\hline
\end{tabular}

Italic items are square root of average variances extracted (AVEs)

CRC composite reliability coefficients, CBa Cronbach's alpha coefficients, AVE average variances extracted, VIF variance inflation factor, ATE attitude toward entrepreneurship, SNR subjective norms, SEF self-efficacy, ITE intentions toward entrepreneurship

As shown in Table 2, the calculated values of Cronbach's alpha for all four constructs are greater than the frequently used threshold value of 0.70 following Vaske et al. (2017). Similarly, the composite reliability coefficients of all four latent variables exceed the threshold value of 0.70 (Peterson and Kim 2013). Thus, all four latent variables qualify both tests of reliability. We can say that the latent variables have good internal consistency and indicators are a reliable measurement of the construct. For discriminate validity, we used square roots of AVE; the results indicate that the items have good discriminant validity as the square roots of AVE is greater than the respective coefficients of correlation with other variables (Johnston et al. 2014). The correlation coefficient values are also lower than the suggested 0.71 standard (Cooke et al. 2016). The VIF values of our constructs remained less than 5 , which indicates that there is no issue of collinearity.

Table 2 indicates that the estimated values of AVEs are greater than the normally adopted standard of 0.50 . Table 3 depicts the results of combined loading and crossloadings. The individual items' loadings have greater values for their respective constructs than other constructs. It can be concluded that all items have valid convergent validity to their respective constructs. The statistics suggest good reliability and validity of the measurement instrument. It is inferred based on the empirical results that our model is free from potential measurement bias.

\subsection{Structural model and hypothesis testing}

After having information about the psychometric properties of the instrument, we proceed to estimate the modeled equation. To capture the moderating role of entrepreneurship education, we used the standard approach previously used by Sharma et al. (2009), then Chin et al. (2012), and most recently Elbaz et al. (2018). To capture the moderating role of entrepreneurship education, we estimated three equations as a standard procedure. The first model using the complete data set. The second model was estimated using the data of the treatment group and the third model was estimated with the data of the control group. The difference in path coefficients, effect size and coefficients of determination was observed to find out the moderating role of entrepreneurship education. Figure 2 graphically depicts the path 
Table 3 Combined loadings and cross-loadings

\begin{tabular}{|c|c|c|c|c|c|c|c|}
\hline & & ATE & SNR & SEF & ITE & Type & $P$ value \\
\hline 1 & ATE1 & 0.844 & -0.030 & 0.008 & 0.135 & Reflect & $<0.001$ \\
\hline 2 & ATE2 & 0.784 & 0.022 & 0.224 & -0.251 & Reflect & $<0.001$ \\
\hline 3 & ATE3 & 0.737 & -0.005 & -0.178 & 0.158 & Reflect & $<0.001$ \\
\hline 4 & ATE4 & 0.825 & -0.248 & -0.188 & 0.211 & Reflect & $<0.001$ \\
\hline 5 & ATE5 & 0.790 & -0.106 & 0.005 & -0.022 & Reflect & $<0.001$ \\
\hline 6 & ATE6 & 0.816 & 0.368 & 0.122 & -0.233 & Reflect & $<0.001$ \\
\hline 7 & SNR1 & 0.025 & 0.872 & 0.064 & -0.198 & Reflect & $<0.001$ \\
\hline 8 & SNR2 & 0.138 & 0.812 & 0.028 & -0.269 & Reflect & $<0.001$ \\
\hline 9 & SNR3 & 0.149 & 0.754 & 0.023 & -0.072 & Reflect & $<0.001$ \\
\hline 10 & SNR4 & -0.103 & 0.752 & 0.009 & 0.179 & Reflect & $<0.001$ \\
\hline 11 & SNR5 & -0.054 & 0.788 & -0.114 & 0.278 & Reflect & $<0.001$ \\
\hline 12 & SNR6 & -0.160 & 0.794 & -0.018 & 0.117 & Reflect & $<0.001$ \\
\hline 13 & SEF1 & -0.020 & -0.272 & 0.822 & 0.272 & Reflect & $<0.001$ \\
\hline 14 & SEF2 & 0.135 & 0.023 & 0.849 & -0.177 & Reflect & $<0.001$ \\
\hline 15 & SEF3 & 0.031 & 0.030 & 0.854 & -0.193 & Reflect & $<0.001$ \\
\hline 16 & SEF4 & -0.025 & 0.145 & 0.833 & -0.232 & Reflect & $<0.001$ \\
\hline 17 & SEF5 & -0.035 & 0.135 & 0.823 & 0.156 & Reflect & $<0.001$ \\
\hline 18 & SEF6 & -0.093 & -0.065 & 0.812 & 0.193 & Reflect & $<0.001$ \\
\hline 19 & ITE1 & -0.164 & 0.126 & 0.016 & 0.776 & Reflect & $<0.001$ \\
\hline 20 & ITE2 & 0.103 & 0.087 & 0.137 & 0.768 & Reflect & $<0.001$ \\
\hline 21 & ITE3 & 0.060 & 0.077 & 0.003 & 0.874 & Reflect & $<0.001$ \\
\hline 22 & ITE4 & -0.089 & 0.086 & -0.008 & 0.875 & Reflect & $<0.001$ \\
\hline 23 & ITE5 & -0.005 & -0.203 & -0.057 & 0.855 & Reflect & $<0.001$ \\
\hline 24 & ITE6 & 0.107 & 0.011 & -0.060 & 0.837 & Reflect & $<0.001$ \\
\hline 25 & ITE7 & -0.014 & -0.171 & -0.018 & 0.827 & Reflect & $<0.001$ \\
\hline
\end{tabular}

Italic items are factor loadings

ATE attitude toward entrepreneurship, SNR subjective norms, SEF self-efficacy, ITE intentions toward entrepreneurship

coefficients $(\beta s)$ and statistical significance ( $P$ values) of the individual predictors as well as the coefficient of determination $\left(R^{2}\right)$ values of all three variants of the model. The parameter coefficients of the first equation (A) were calculated by overall data including treatment group as well as the control group. The estimated parameters in case of second equation (B) were based on data of the treatment group only and the third equation (C) was estimated for parameters of the control group. The results indicate that the path coefficients of attitude toward entrepreneurship (ETE, $\beta=0.24$ ), subjective norms (SNR, $\beta=0.27$ ) and self-efficacy (SEF $\beta=0.36)$ are significant predictors at $99 \%$ confidence level. The results favor the acceptance of suggested null hypotheses namely $\mathrm{H} 1, \mathrm{H} 2$ and $\mathrm{H} 3$. These findings are consistent with the predictions of Planned Behavior Theory. The coefficient of determination value $\left(R^{2}=0.53\right)$ suggests that variation in intentions toward entrepreneurship is $53 \%$ explained collectively by the three independent variables. The results indicate that self-efficacy has more contribution to intentions toward entrepreneurship with the highest path coefficient than subjective norms and attitude toward entrepreneurship, respectively. To capture the mediating role of entrepreneurship education, the equation was separately estimated for treatment group (who completed entrepreneurship courses) and control group (who did not study entrepreneurship courses). 


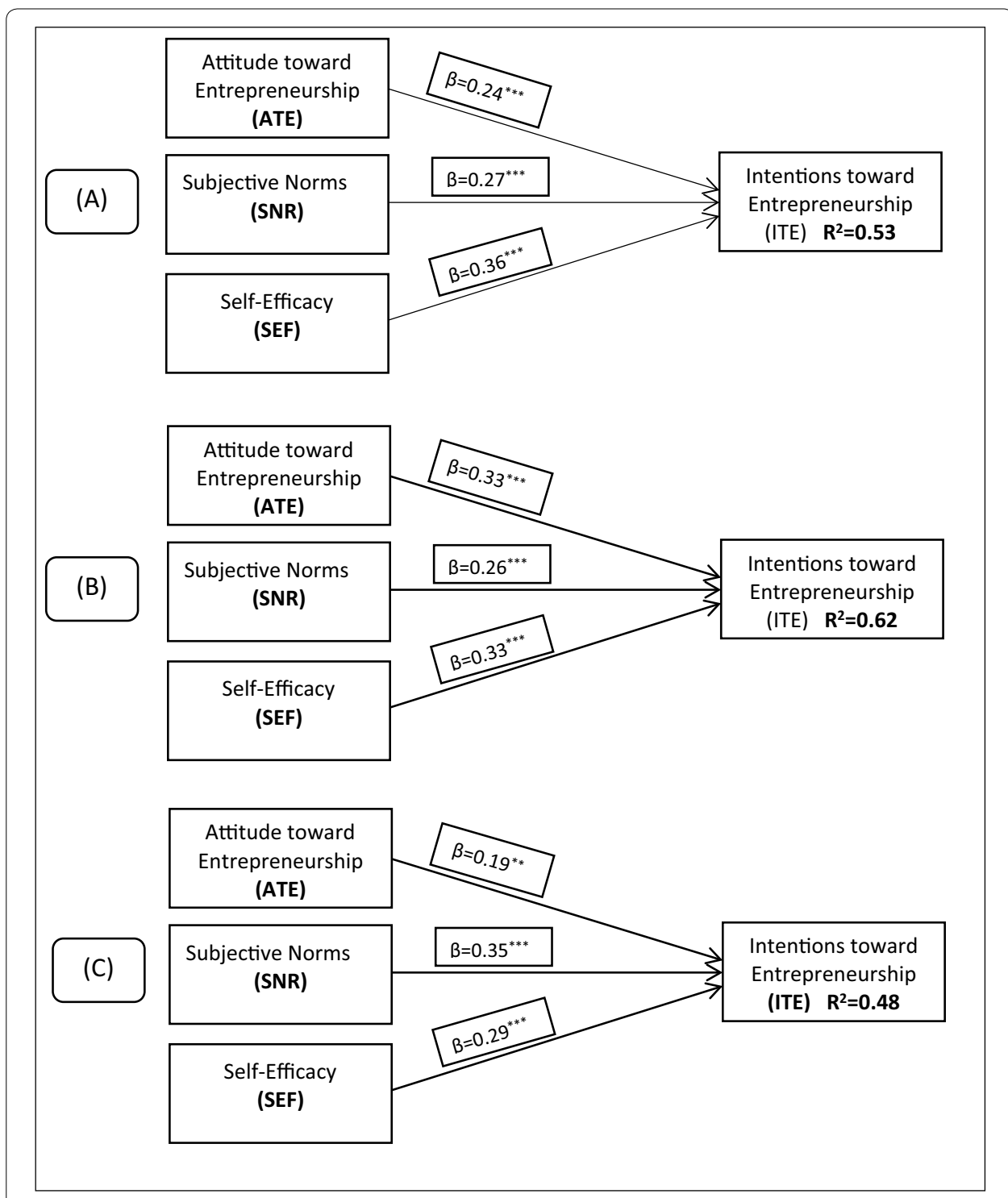

Fig. 2 Structural model and hypothesis testing (combine group A, treatment group B, and control group C)

Table 4 Path coefficient comparison

\begin{tabular}{|c|c|c|c|c|c|c|c|c|c|}
\hline \multirow[t]{2}{*}{ Path coefficients } & \multicolumn{3}{|c|}{$\begin{array}{l}\text { Combined results } \\
R^{2}=0.533\end{array}$} & \multicolumn{3}{|c|}{$\begin{array}{l}\text { Treatment group } \\
R^{2}=0.621\end{array}$} & \multicolumn{3}{|c|}{$\begin{array}{l}\text { Control group } \\
R^{2}=0.480\end{array}$} \\
\hline & $B$ & Effect size & $P$ value & $\beta$ & Effect size & $P$ value & $B$ & Effect size & $P$ value \\
\hline $\mathrm{ATE} \rightarrow \mathrm{ITE}$ & 0.239 & 0.141 & $<0.001$ & 0.331 & 0.235 & $<0.001$ & 0.191 & 0.095 & 0.032 \\
\hline $\mathrm{SNR} \rightarrow \mathrm{ITE}$ & 0.266 & 0.164 & $<0.001$ & 0.257 & 0.174 & 0.003 & 0.346 & 0.212 & $<0.001$ \\
\hline $\mathrm{SEF} \rightarrow \mathrm{ITE}$ & 0.363 & 0.228 & $<0.001$ & 0.330 & 0.212 & $<0.001$ & 0.287 & 0.173 & 0.002 \\
\hline
\end{tabular}

The statistics in case of treatment group (B) indicate that the parameter coefficients (ATE) $\beta=0.33$, (SNR) $\beta=0.26$ and (SEF) $\beta=0.33$ are significant at $99 \%$ confidence level and coefficient of determination is $R^{2}=0.62$. In case of the control group, the 
results indicate that the parameter coefficient of (ATE) $\beta=0.19$ is significant at $95 \%$ confidence level and parameter coefficients of (SNR) $\beta=0.35$ and (SEF) $\beta=0.29$ are significant at $99 \%$ confidence level. The $R^{2}$ value is 0.48 which is lowest in all three cases.

The comparative results of the three estimated equations are reproduced in Table 4. It is found that entrepreneurship education moderates the relationship between attitude toward entrepreneurship and entrepreneurial intentions, as indicated by the path coefficient value. In case of treatment group, the path coefficient ATE $\rightarrow$ ITE is $\beta=0.331$ significant at $99 \%$ confidence level. However, in case of control group, the value of path coefficient is $\beta=0.191$ at $95 \%$ confidence level. The individual effect size in case of treatment group also favors the acceptance of $\mathrm{H} 4$ null hypothesis. The path coefficient $\mathrm{SNR} \rightarrow \mathrm{ITE}$, in case of treatment group, is $\beta=0.257$ significant at $99 \%$ confidence level whereas in case of control group, $\beta=0.346$ significant at $99 \%$ confidence level. The findings favor the acceptance of $\mathrm{H} 5$ null hypothesis. This result also signifies the moderating role of entrepreneurship education on the relationship between subjective norms and entrepreneurial intentions. It can be observed that education reduces the impact of subjective norms on entrepreneurial intentions. It indicates that student's intentions toward entrepreneurship are less influenced by their environment if imparted entrepreneurship education. The path coefficient SNR $\rightarrow$ ITE in case of treatment group is $\beta=0.330$ significant at $99 \%$ confidence level and in case of control group is $\beta=0.287$ significant at $99 \%$ confidence level. Similarly, the individual effect size is 0.212 in treatment group and in case of control group, it is 0.173 . These results indicate that entrepreneurship education affects the relationship between self-efficacy and entrepreneurial intentions positively. Based on the results, the $\mathrm{H} 6$ null hypothesis is also accepted.

\section{Conclusions}

This study aims to investigate the impact of attitude toward entrepreneurship, subjective norms and self-efficacy on entrepreneurial intentions and moderating role of entrepreneurship education onto the relationship among them. The target population of this study is students of various disciplines in the Sultanate of Oman. We found robust results to satisfy the minimum standards suggested for the measurement quality of the instrument. The SEM results suggest that attitude toward entrepreneurship, subjective norms and self-efficacy are significant predictors of entrepreneurial intentions. The results are in accordance with the suggested relationship among the modeled variables by Planned Behavior Theory. In addition to that, we also found evidence to affirm that entrepreneurship education plays a moderating role in strengthening the relationship between attitude toward entrepreneurship and entrepreneurial intentions as well as selfefficacy and entrepreneurial intentions. However, entrepreneurship education weakens the relationship between subjective norms and entrepreneurial intentions.

It is inferred from the empirical results that entrepreneurship education effectively contributes to developing entrepreneurial intentions in case of Sultanate of Oman. Entrepreneurship education positively contributes to strengthening and channeling the entrepreneurial attitude toward entrepreneurial intentions. Entrepreneurship education also improves the level of perceived self-efficacy and resultantly derives toward 
entrepreneurship intentions. The results revealed that entrepreneurship education weakens the relationship between subjective norms and entrepreneurship intentions which indicate that education enhances the self-reliance among the students by reducing the influence of social norms.

The results of this study have great importance for policymakers as most of the previous studies related to Oman had investigated that cultural factors and lack of entrepreneurship education in addition to lack of other support programs have closed the door for new business in Oman. Entrepreneurship education has been started in recent years in all higher education institutions along with some other support facilities may effectively influence the students' intentions in a positive way. The policymakers should focus on strengthening entrepreneurship education, R \& D and technological infrastructure.

The study is limited to three variables, i.e., attitude toward entrepreneurship, subjective norms and self-efficacy. The three variables were selected due to their suitability for local culture, students' characteristics and increasing entrepreneurship education. Moreover, only higher education institutions including colleges and universities in Oman have been considered in this study.

A separate research study may further enhance our understanding that how entrepreneurship education negatively altered the relationship between subjective norms and entrepreneurship intentions. Cultural factors along with the informal institutions may provide better insight into this highly important research problem.

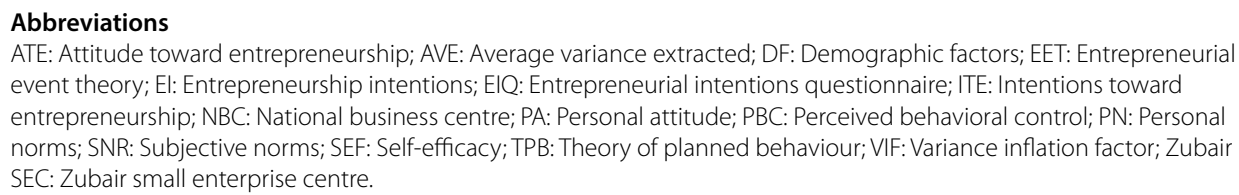
event theory; El: Entrepreneurship intentions; EIQ: Entrepreneurial intentions questionnaire; ITE: Intentions toward entrepreneurship; NBC: National business centre; PA: Personal attitude; PBC: Perceived behavioral control; PN: Personal norms; SNR: Subjective norms; SEF: Self-efficacy; TPB: Theory of planned behaviour; VIF: Variance inflation factor; Zubair SEC: Zubair small enterprise centre.

Acknowledgements

Not applicable.

Authors' contributions

IAS developed manuscript, SA analyzed data and SJ developed questionnaire and collected all primary data. All authors read and approved the final manuscript.

Funding

Not applicable.

Availability of data and materials

The datasets used and/or analyzed during the current study are available from the corresponding author on reasonable request.

Competing interests

The authors declare that they have no competing interests.

Author details

${ }^{1}$ Department of Business Administration, Yorkville University, New Westminster, BC, Canada. ${ }^{2}$ Department of Business Administration, College of Applied Sciences, Salalah, Oman. ${ }^{3}$ Administration Department, College of Applied Sciences, Salalah, Oman.

Received: 12 November 2019 Revised: 22 January 2020 Accepted: 15 February 2020

Published online: 27 February 2020

\section{References}

Ajzen I (1991) The theory of planned behaviour. Organ Behav Hum Decis Process 50(2):179-211

Badulescu A, Badulescu D (2013) How entrepreneurial are doctoral students? Some evidence from Romania. J East Eur Res Bus Econ 2013:1-10 
Bartlett JE, Kotrlik JW, Higgins CC (2001) Organizational research: determining appropriate sample size in survey research. Inf Technol Learn Perform J 19(1):43-50

Cheng MY, Chan WS, Mahmood A (2009) The effectiveness of entrepreneurship education in Malaysia. Educ Train 51:555-566

Chin WW (1998) The partial least squares approach for structural equation modeling. In: Marcoulides GA (ed) Methodology for business and management. Modern methods for business research. Lawrence Erlbaum Associates Publishers, New Jersey, pp 295-336

Chin WW, Thatcher JB, Wright RT (2012) Assessing common method bias: problems with the ULMC technique. MIS Q 36(3):1003-1019

Cooke R, Dahdah M, Norman P, French DP (2016) How well does the theory of planned behaviour predict alcohol consumption? A systematic review and meta-analysis. Health Psychol Rev 10(2):148-167

Costa T, Superior E, Empresariais DC (2016) Student's entrepreneurial intention: ESCE and FEA comparison. XXVI Jornadas Luso-Espanholas de Gestão Cientifica, Edição: 7, Ed. Especial

Davidsson P (1995) Determinants of entrepreneurial intentions. Paper prepared for the RENT IX workshop, Piacenza, Italy, 23-24. https://pdfs.semanticscholar.org/8690/66b0890c6d097443bfof6f3a0ca983bfa12b.pdf. Accessed 7 June 2019

Delmar F, Davidsson P (2000) Where do they come from? Prevalence and characteristics of nascent entrepreneurs. Entrepreneurship Reg Dev 12(1):1-23

Dinis A, do Paço A, Ferreira J, Raposo M, Gouveia Rodrigues R (2013) Psychological characteristics and entrepreneurial intentions among secondary students. Educ Train 55(8/9):763-780

Elbaz AM, Agag GM, Alkathiri NA (2018) How ability, motivation and opportunity influence travel agents performance: the moderating role of absorptive capacity. J Knowl Manage 22(1):119-141

European Commission (2006) Entrepreneurship education in Europe: fostering entrepreneurial mindsets through education and learning. In: Final proceedings of the conference on entrepreneurship education in Oslo, 26-27 October 2006

Fatoki O, Oni O (2014) Students' perception of the effectiveness of entrepreneurship education at a South African University. Mediterr J Soc Sci 5(20):5850591

Fayolle A, Gailly B (2008) From craft to science teaching models and learning processes in entrepreneurship education. J Eur Ind Train 32(7):569-593

Grilo I, Thurik AR (2005) Latent and actual entrepreneurship in the Europe and the US: some recent developments. Int Entrepreneurship Manage J 1(4):441-459

Haenlein M, Kaplan AM (2004) A beginner's guide to partial least squares analysis. Underst Stat 3(4):283-297

Hair JF, Ringle CM, Sarstedt M (2011) PLS-SEM: indeed a silver bullet. J Mark Theory Pract 19(2):139-152

Hair JF Jr, Hult GTM, Ringle C, Sarstedt M (2016) A primer on partial least squares structural equation modelling (PLSSEM). Sage Publications, Thousand Oaks

Heuer A, Kolvereid L (2014) Education in entrepreneurship and the theory of planned behaviour. Eur J Train Dev 38(6):506-523

Jaafa M, Abdul Aziz AR (2008) Entrepreneurship education in developing country exploration on its necessity in the construction programme. J Eng Des Technol 6(2):178-189

Johnston M, Dixon D, Hart J, Glidewell L, Schröder C, Pollard B (2014) Discriminant content validity: a quantitative methodology for assessing content of theory-based measures, with illustrative applications. Br J Health Psychol 19(2):240-257

Khuong MN, Huu An N (2016) The factors affecting entrepreneurial intention of the students of Vietnam University -a mediation analysis of perception toward entrepreneurship. J Econ Bus Manage 4(2):104-111

Krueger NF, Reilly MD, Carsrud AL (2000) Competing models of entrepreneurial intentions. J Bus Ventur 15(5):411-432

Lee SM, Chang D, Lim SB (2005) Impact of entrepreneurship education: a comparative study of the U. S. and Korea. Int Entrepreneurship Manage J 1:27-43

Liñán F, Chen Y (2006) Testing the entrepreneurial intention model on a two-country sample. Working Paper 0607, Department d'Economia de l'Empresa. https://core.ac.uk/download/pdf/13283138.pdf. Accessed 10 June 2019

Liñán F, Chen Y (2009) Development and cross-cultural application of a specific instrument to measure entrepreneurial intentions. Entrepreneurship Theory Pract 33(3):593-617

Liñán F, Urbano D, Guerrero M (2011) Regional variations in entrepreneurial cognitions: start-up intentions of university students in Spain. Entrepreneurship Reg Dev 23(3-4):187-215

Lorz M, Müller S, Volery T (2011) Entrepreneurship education: a meta-analysis of impact studies and applied methodologies, Conference Paper, FGF G-Forum 2011. Zurich

Lowry PB, Gaskin J (2014) Partial Least Squares (PLS) Structural equation modelling (SEM) for building and testing behavioural causal theory: when to choose it and how to use it. IEEE Trans Prof Commun 57(2):123-146

Luiz J, Mariotti M (2011) Entrepreneurship in an emerging and culturally diverse economy: a South African survey of perceptions. S Afr J Econ Manag Sci 14(01):47-65

Magd HA, McCoy MP (2014) Entrepreneurship in Oman: paving the way for a sustainable future. Procedia Econ Finance 15:1632-1640

Mushtaq HA, Hunjra Al, Niazi GSK, Rehman K, Azam RI (2011) Planned behaviour entrepreneurship and intention to create a new venture among young graduates. Manage Mark Chall Knowl Soc 6(3):437-456

Nazri MA, Aroosha H, Omar NA (2016) Examination of factors affecting youths' entrepreneurial intention: a cross-sectional study. Inf Manage Bus Rev 8(5):14-24

Owoseni O, Akambi PA (2010) Entrepreneurial intentions: a theoretical framework. J Manage Corp Gov 2(4):132-148

Packham G, Jones P, Miller C, Pickernell, D, Thomas B (2010) Attitudes towards entrepreneurship education: a comparative analysis. Educ Train 52(8/9):568-586

Peterson RA, Kim Y (2013) On the relationship between coefficient alpha and composite reliability. J Appl Psychol 98(1):194-198

Rasli AM, Khan SR, Malekifar S, Jabeen S (2013) Factors affecting entrepreneurial intention among Graduate Students of Universiti Teknologi Malaysia. Int J Bus Soc Sci 4(2):182-188 
Reynolds P, Storey D, Westhead P (1994) Cross-national comparison of the variation in new firm rates. Reg Stud 28(4):443-456

Sahinidis AG, Vassiliou EE, Hyz AB (2014) Factors affecting entrepreneurs'intention to start a new venture: an empirical study. Int J Strateg Innov Mark 1:148-162

Sarstedt M, Ringle CM, Smith D, Reams R, Hair JF Jr (2014) Partial least squares structural equation modelling (PLS-SEM): a useful tool for family business researchers. J Fam Bus Strateg 5(1):105-115

Sarstedt M, Ringle CM, Hair JF (2017) Partial least squares structural equation modelling. In: Handbook of market research. Springer International Publishing. pp 1-40

Shapero A, Sokol L (1982) Social dimensions of entrepreneurship. In: Kent CA, Sexton DL, Vesper KH (eds) Encyclopedia of entrepreneurship. Prentice Hall, Englewood Cliffs, pp 72-90

Sharma D, Borna S, Stearns JM (2009) An investigation of the effects of corporate ethical values on employee commitment and performance: examining the moderating role of perceived fairness. J Bus Ethics 89(2):251-260

Solesvik M, Westhead P, Kolvereid L, Matlay H (2012) Student intentions to become self-employed: the Ukrainian context. J Small Bus Enterp Dev 19(3):441-460

Souitaris V, Zerbinati S, Al-Laham A (2007) Do entrepreneurship programmes raise entrepreneurial intention of science and engineering students? The effect of learning, inspiration and resources. J Bus Ventur 22(4):566-591

Startup Oman (2018) A non governmental project, Mudlij LLC. http://www.startupoman.om/program-services. Accessed 5 June 2019

Storey DJ (1994) Understanding the small business sector. Routledge, London, p 1994

Taha KA, Ramlan SN, Noor IM (2017) The factors affecting entrepreneurial intentions of university students in Malaysia. Int J Bus Technopreneurship 7(2):189-202

Thompson ER (2009) Individual entrepreneurial intent: construct clarification and development of an internationally reliable metric. Entrepreneurship Theory Pract 33(3):669-694

Trading Economics (2018) Oman unemployment rate. https://tradingeconomics.com/oman/unemployment-rate. Accessed 31 Jan 2018

Turker D, Selcuk SS (2008) Which factors affect entrepreneurial intention of university students? J Eur Ind Train 33(2):142-159

UNESCO (undated) Entrepreneurship Education in Oman, United Nations, Educational, Scientific, Cultural Organizations. http://www.unevoc.unesco.org/fileadmin/user_upload/pubs/Entrepreneurship\%20education\%20-\%200man.pdf. Accessed 5 Feb 2018

Vaske JJ, Beaman J, Sponarski CC (2017) Rethinking internal consistency in Cronbach's Alpha. Leis Sci 39(2):163-173

Wang CK, Wong P (2004) Entrepreneurial interest of university students in Singapore. Technovation 24(2):163-172

\section{Publisher's Note}

Springer Nature remains neutral with regard to jurisdictional claims in published maps and institutional affiliations.

\section{Submit your manuscript to a SpringerOpen ${ }^{\circ}$ journal and benefit from:}

- Convenient online submission

- Rigorous peer review

- Open access: articles freely available online

- High visibility within the field

Retaining the copyright to your article

Submit your next manuscript at $\boldsymbol{\nabla}$ springeropen.com 